\title{
Measuring the Spiritual Brand Attribute of Islamic Banks
}

\author{
Siti Ngayesah Ab Hamid ${ }^{* a}$, Wan Jamaliah Wan Jusoh ${ }^{\mathrm{b}}$ \& Suharni Maulan ${ }^{\mathrm{c}}$ \\ ${ }^{* a, b}$ Faculty of Economics and Management, Universiti Kebangsaan Malaysia, \\ Bangi, Selangor, Malaysia \\ ${ }^{\mathrm{c}}$ Kulliyyah of Economics and Management Sciences, \\ International Islamic University Malaysia, Kuala Lumpur, Malaysia
}

\begin{abstract}
Islamic banking institutions are different from their conventional counterparts as they incorporate religious and spiritual values in their operations. Despite this significant difference, few studies have investigated this spiritual aspect especially from the perspective of the brand. The main purpose of this study is to develop a valid and reliable scale to measure the spiritual brand attribute of Islamic banks. Based on the result of the interviews and review of literature, 28 items were proposed and analysed using exploratory factor analysis (EFA) and confirmatory factor analysis (CFA). A total of 14 items remain on the final scale classified in three dimensions which are beliefs, ethics, and corporate social responsibility (CSR). The new brand attribute scale is different from the existing scale as it focuses mainly on the spiritual and religious aspect incorporated into the Islamic banking brand.
\end{abstract}

Keywords: Brand attribute, spiritual, Islamic bank, Islamic brand

\subsection{Introduction}

The Islamic banking system has grown tremendously throughout the world since its first establishment in the 1970s. Starting from a remote area of Egypt, the Islamic banking practice has spread not only to the other Islamic countries but also to the West. The potential and popularity of Islamic banking system motivated not only Islamic banks, but also large international conventional banks to offer similar products and services. As a consequence, strong competition exists not only between full-fledged Islamic banks but also between Islamic and conventional banks that operate side by side. As banks have started offering almost similar products and services, intensified branding effort is needed to ensure differentiation and success. However, in comparison to goods which are usually being promoted using a single branding strategy, service firms like

Corresponding Author: Tel: +603-8921 3963

E-mail: ctngayesah@ukm.edu.my 
banks are commonly viewed as companies (de Chernatony \& Dall'Olmo Riley, 1999) and as such should be managed through a corporate branding strategy.

In order to understand the corporate brand, de Chernatony (2002) has developed a brand triangle model that classifies brand into two types of values which are functional value and emotional value. The concept of brand triangle originated from Park, Jaworski, and Maclnnis (1986). They stated that the concept of a brand is influenced by three types of consumer needs which are functional needs, symbolic needs and experiential needs. However, the spiritual needs or values which are important for Muslim consumers are not included in these two concepts.

In the context of Islamic brand however, several studies have proposed the existence of spiritual dimension or spiritual brand attribute. For example, Aoun and Tournois (2015) have proposed three dimensions of a holistic brand which are functional, emotional and spiritual brand attributes. On the other hand, Mourad and Karanshawy (2013) suggested the existence of the spiritual dimension in evaluating Islamic higher education institutions and found significant support for the proposition. In the context of Islamic banks, few studies could be found trying to relate the Islamic banking brand with the religion. Maulan, Omar, and Ahmad (2016) proposed a halal brand association named as HalBA and identified three related dimensions which are shari'ah compliance, God-consciousness, and CSR. On the other hand, Osman (2010) studied the corporate image of Islamic banking institutions and found two dimensions which are CSR and God-consciousness to be related to the target customers belief system and faith. Theoretically, apart from the emphasis on halal and haram, and the incorporation of Shari'ah compliance, the soul of the Islamic brand itself is to achieve good deed, which not only reached through commercial and material gains but should be motivated by spiritual and ethical dimension (Alserhan, 2010). For Muslims, consuming an Islamic brand is more than just a means of transaction, but could also be translated as worship of Allah (Md Husin \& Ab Rahman, 2013) and a way of expecting rewards from Allah (Alserhan, 2010).

Despite the existence of several studies emphasising on the spiritual brand attribute, most of the measurements were developed individually, without considering the redundancy that may occur between the spiritual brand and the other attributes of the brand which are functional and emotional attributes. Therefore, in order to ensure that the measurement of the spiritual attribute is focused on the spiritual aspect only, this study intend to develop and validate a scale to measure spiritual brand attributes of Islamic banks without overlooking the importance of functional and emotional brand attributes.

The remainder of this paper is divided into the following sections. The first section is a literature review on the concept of brand and the spiritual brand attribute. Second, 
the procedures used to develop the scale and to assess the psychometric properties are explained. The last section includes conclusion, discussion of the implications of the study, limitations as well as suggestions for future research.

\subsection{Literature Review}

\subsection{The Conceptualization of Brand}

The concept of the brand, especially in the context of a corporate brand, has been simplified by de Chernatony (2002) in a model known as the brand triangle. The brand triangle model depicted in Figure 1 categorized brand into three levels which started from functional value, followed by emotional value and promised experience.

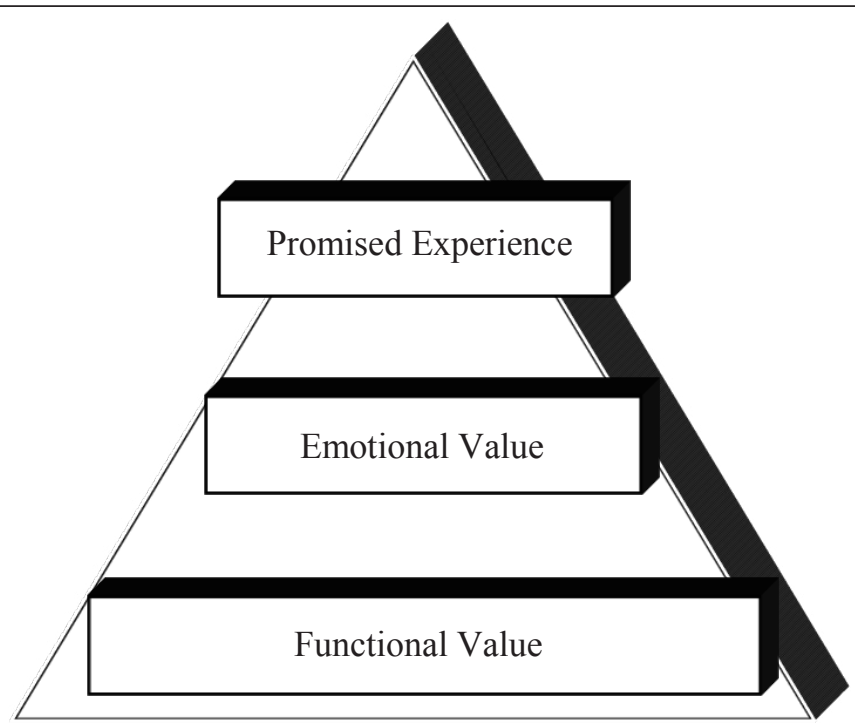

Figure 1. Brand triangle model (adopted from de Chernatony (2002).

In other words, from the customers' point of view, the initial decision to choose a brand is usually based on a rational assessment or functional value before considering the emotional value (de Chernatony, 2002). Functional value according to de Chernatony (2002) concerns what the customer receives which is mainly based on the cognitive elements. Emotional values, on the other hand, refer to how the customer receives the functional value, or the consequence of the values received from the brand functional features (de Chernatony, 2002). Referring to the model, it could be concluded that 
brand importance moves from the functional level to the emotional level and finally to the promised experience (de Chernatony \& Christodoulides, 2004). Simply, customer views towards a brand start from their cognitive state, to the affective state and finally to the conative state.

On a different note, in the context of Islamic brand, or brands incorporating Islamic values, Aoun and Tournois (2015) proposed a slightly different model on the level of brand known as a holistic brand. This newly modified model includes spiritual value in addition to functional and emotional values. This is in line with al-Ghazali who states that a person's perception, affection, cognition and behaviour depends on his/ her spiritual state (Ali, 1995). Al-Ghazali state that "the soul which perceives by means of the insight is of greater value than the body which perceives by means of the eyes' (Ihya' Ulumuddin). Thus, in the context of Islamic brand, it is proposed that the spiritual aspect or attribute of the brand affects customer's evaluation of the functional and emotional attributes, as well as the delivery of the promised experience. In the case of this study, it could be said that the Islamic banking brand is comprised of a cluster of spiritual, functional, and emotional values.

\subsection{Spiritual Brand Attributes}

Despite various studies on the functional and emotional values or brand attribute, few studies could be found integrating the spiritual aspect of a brand (El-Amir \& Burt, 2010). In general, spirituality has been defined in various studies as a concept related to religion, nature and humanistic (Emmons, 2006). It relates deeply with the meaning of life, ethical issues and care of the environment (Marmor-Lavie, Stout, \& Lee, 2009). In the context of Islam, spirituality is defined from the perspective of taqwa or Godconsciousness which concerns the connection with Allah that influences individuals' relationship with human and nature and their perspective on the sense of meaning and their self-worth (Bonab, Miner, \& Proctor, 2013). Islamic spirituality is different from secularistic spirituality as it is based on the Quran and Sunnah (Ahmad \& Khan, 2016). Islamic spirituality concerns the belief system and the Oneness of Allah, which would influence every aspect of a Muslim's daily life. Spirituality shapes values, actions, and thoughts (Ahmad \& Khan, 2016) in various aspects of life including marketing and branding decision as it could influence consumption and brand relation (Marmor-Lavie et al., 2009).

In the context of the brand, several studies have been conducted on the spiritual aspect. For example, Mourad and Karanshawy (2013) apply Gad's (2003) 'brand mind space' proposition that focuses on the functional, social, mental and spiritual dimensions of a brand. Focusing on Islamic higher education institutions as a sample, Mourad and Karanshawy (2013) found partial support for the spiritual aspect as compared to the functional aspect. On the other hand, in the context of halal cosmetics, Aoun and Tournois 
(2015) tried to explore the existence of spiritual attribute by using a qualitative approach. Findings of the interview reveal four dimensions of the spiritual attribute which are (1) spiritual ethos and belief system; (2) wholesomeness and health; (3) sustainable and eco-ethical philosophy; and (4) inclusiveness. In the Islamic banking setting, Maulan et al. (2016) and Osman (2010) try to determine religious attributes differentiating Islamic banking brand from the conventional brand. Using the Institutional Theory as the basis, Osman (2010) proposed two attributes which are the Corporate Social Responsibility (CSR), and God-consciousness to represent the Islamic bank's institutional image. On the other hand, using a brand association concept, Maulan et al. (2016) proposed three dimensions which are CSR, God-consciousness and Shari'ah compliance to be associated with the Islamic banks. However, despite Osman (2010) and Maulan et al. (2016) objectives of understanding customers perception towards the religious aspect of Islamic bank, these studies were not conducted with the consideration of the other aspects of brand which are the functional and emotional attributes. As such, attributes found by the study may not specifically represent the spiritual attribute only, but could also include the other brand attributes. This is proven by the inclusion of Shari'ah compliance which is also considered as a functional or service quality aspect by Abduh (2011), and Othman and Owen (2001). However, based on a preview of various literature, and based on the result of semi-structured interviews conducted in this study three aspects were found to suit the spiritual brand attribute which are ethics, CSR and beliefs.

\subsection{Ethics}

Ethic refers to 'the science of conduct', which deals with two opposing moral questions such as good or bad, right or wrong and virtues or vice. It involves moral practices and is defined as moral values and moral ailments or ills (Dasti \& Sitwat 2014). Ethics from the Islamic point of view involves three important elements which are adl (justice), amanah (trust) and ihsan (benevolence) (Beekun \& Badawi 2005). However, the core of Islamic ethics is said to lie on the concept of tawhid or acceptance of the oneness and sovereignty of God (Mansour, Ben Jedidia \& Majdoub 2015). The concept of tawhid is in line with the God-consciousness concept of the Islamic bank mentioned by Maulan et al. (2016) and Osman (2010) which emphasized the Shari'ah principle as the foundation of Islamic financial ethics. Ethics in Islamic banking is closely related to the maslahah. Hence, any financing and investment decision should take into account the impact on the society (Mansour et al. 2015). Naturally, the Islamic bank is prohibited from financing projects that are conflicting with Islamic morality such as casinos, breweries and night clubs which would be detrimental to the society (Ahmad 2000). Furthermore, in order to reflect an Islamic ethical virtue such as justice, transparency and honesty, products of the Islamic bank are also expected to reflect the substance of Islamic finance (Maulan et al. 2016) such as the prohibition of riba as 
it represents a source of unfair and unjustified advantage which could cause not only economic but also social crisis (Maulan et al. 2016). In the context of this study, ethics is defined as the conducts or actions of the bank which is in line with the Islamic moral values and the shari'ah.

\subsection{Corporate Social Responsibility}

CSR in Islam is closely related to moral and religious obligations that require companies to be 'good' regardless of the financial consequence (Dusuki 2008b). The Islamic CSR generally requires the companies to go beyond the profit maximisation goal, by involving corporate activities such as good environmental activities, philanthropic contributions, socially responsible programs and occupational safety (Dusuki 2008b). In the context of the Islamic bank, the CSR activities should be driven towards the objectives of realising a just and comfortable life for the ummah (Ismail \& Muqorobin 2017) and contributing towards the achievement of socio-economic equilibrium, which is the basic goal behind the prohibition of riba (Warde 2000). CSR in Islam is more than a tool of enhancing goodwill or improving financial achievement (Dusuki, 2008b), as it involves not only ethical and moral judgements but also stands on the foundation of God-consciousness or Tawhidic paradigm (Dusuki, 2008b). Thus, any firm that operates based on the principle of the shari'ah should practice CSR as that would distinguish an Islamic firm from a conventional one (Dusuki, 2008b). In line with the religious obligations and the spirit of brotherhood as well as social equality expected from the Islamic bank, Maulan et al. (2016) defined CSR as the bank's moral and religious initiatives undertaken based on the belief that the Islamic bank is required to provide social welfare apart from its profit motive.

\subsection{Beliefs}

One of the attributes said to be associated with Islamic banks is beliefs. This is because Islamic banks are acknowledged to be in line with the Muslim consumers' beliefs and therefore is hoped to be able to protect the customers' religion and to bring them nearer to the Creator. The aspect of beliefs is related to the concept of Tawhid (the Oneness of God) and as such is also associated with rewards and sins in this world and the hereafter. It is also attributed to the sense of connectedness with the Creator, including the sense of fear of Allah's punishment, hope for forgiveness, and yearning for Allah's love and compassion (Dasti \& Sitwat 2014). Religious belief is the essence of Islamic banking business as the objective of the Islamic bank lies on Allah as the Creator of the universe, and the ultimate direction of human economic activities (Mohammad \& Shahwan 2013). The Islamic bank is established with the purpose of providing an alternative to the riba-based conventional financial institutions which is forbidden in Islam (Ahmad, Kashif-ur-Rehman \& Afzal 2011). The Qur'an has specifically warned those who take riba as in Surah an-Nisa' verse 161: 
"And (for) their taking of usury while they had been forbidden from it, and their consuming of the people wealth unjustly. And we have prepared for the disbelievers among them a painful punishment."

Hence, the Islamic banking operation cannot be dissociated from religious belief, as it covers both worldly gain and the hereafter (Dusuki 2008a). In addition, the principal goal of banks is to ensure the well-being of human beings in terms of physical and spiritual satisfaction, as well as happiness in the world and hereafter (Dusuki 2008a).

\subsection{Methodology}

\subsection{Development of Scale to Measure the Spiritual Brand Attribute of Islamic Banks}

The procedure used to develop a scale measuring the spiritual brand attribute were adapted from Parasuraman, Zeithaml, and Malhotra (2005). The data collection was divided into two stages which were quantitative and qualitative.

\subsection{Item generation}

At the first stage, semi-structured interviews were conducted with nine relevant individuals. As a general rule, a sample size of eight is sufficient, especially if the result would be further clarified with survey research (Gray, 2004). In the case of this study, the interviews were halted when data reached saturation (Gray, 2004), because new information were no longer obtained from additional interviews.

In general, each interview session took between 30 minutes to one hour. All sessions were recorded while at the same time notes were taken in the event the recording malfunctioned. A list of questions developed beforehand based on the literature were used to guide the interviewer, but interviewees were probed for further clarification. The questions were used flexibly according to the interviewees' responses, as long as it is within the intended objectives (Gray, 2004). The interview questions are as follows:

Q1. Currently, what kind of image is portrayed by Islamic banks to the consumers?

Q2. In an ideal situation, what kind of image do you think should be portrayed by an Islamic bank?

Q3. Do you think religious/spiritual related aspect influence consumers' decision to choose an Islamic bank?

Q4. Can you share in general among the activities undertaken by Islamic bank that may shape customers' perception?

Q5. Are there any aspects related to religion, faith, and beliefs conveyed by Islamic bank through its brand? 
In the process of interviewing the respondents, data were transcribed and examined to ensure it has reached saturation before the procedure was stopped (Gray, 2004). The interview findings were then compared with prior literature focusing on the spiritual dimensions proposed by Aoun and Tournois (2015), Osman et al. (2010) and Maulan et al. (2016) and content analysis was conducted.

Based on the findings reported in previous literature, a directed content analysis approach was used to analyse the interview findings (selected excerpts of the interviews are listed in Appendix A). Three relevant themes were identified, namely beliefs, ethics and corporate social responsibility (CSR). A scale measurement consisting of 40 items representing the three key dimensions was proposed and submitted to a panel of experts for content validity. Finally, twenty-eight items were retained as collectively agreed by the experts (Appendix B), while 12 items rated as not representative were dropped from further validation.

\subsection{Exploratory Factor Analysis}

In the second stage, a quantitative study was conducted. Questionnaires prepared in English and Malay were distributed to 420 respondents with characteristics similar to those in the actual study. From the 420 questionnaires distributed, 390 were returned, but only 384 were considered valid for further analysis. The questionnaires were split into two in which 140 were used for exploratory factor analysis (EFA) (Ramayah, Cheah, Chuah, Ting, \& Memon, 2018). As a general rule, preferably, a minimum sample size for EFA should be 100 while the desired ratio is five times the number of items (Hair, Black, Babin, \& Anderson, 2010). Since the number of items analysed for spiritual brand attributes is 28, 140 was considered suitable. Using the 140 responses, an examination of coefficient alpha was undertaken to ensure the reliability of more than 0.6 (Sekaran, 2000). Then, EFA was conducted to confirm the availability of the proposed dimensions and to ensure the appropriateness of items in the dimension (Sekaran, 2003).

On examination of the correlation matrix, 13 items (ETHIC3, ETHIC4, ETHIC6, CSR1, CSR7, CSR8, CSR9, BELIEF2, BELIEF6, BELIEF7, BELIEF8, BELIEF9, BELIEF11) were deleted as the correlations were greater than 0.7 (Hair et al., 2010). Furtheremore, the anti-image correlation was inspected to ensure the Measure of Sampling Adequacy (MSA) is above 0.5 (Hair et al., 2010). The Kaiser-Meyer-Olkin (KMO) value is 0.948, and Bartlett's test of sphericity is significant $(\mathrm{p}=0.000)$ demonstrating that the factors were related and factor analysis was appropriate (Pallant, 2005). Since the data was fit, factor analysis was performed.

Using principal component extraction and varimax rotation, three homogeneous subscales with eigenvalues exceeding 1 , explained $71.415 \%$ of the variance revealed. 
Communalities were then checked to ensure no extraction was below 0.5. Further inspection showed one item (CSR2) was cross-loaded on different factors and was thus deleted. The final 14 items explained $71.864 \%$ of the total variance. These items loaded in three factors with factor loadings ranging between 0.525 and 0.820 and communalities between 0.610 and 0.822 . A communality of more than 0.50 is sufficient while for a sample size between 120-150, a factor loading of more than 0.50 is considered acceptable (Hair, Black, Babin, Anderson, \& Tatham, 2006). Table 1 presents the EFA results.

Table 1

EFA results

\begin{tabular}{|c|c|c|c|c|}
\hline \multirow{2}{*}{ Items } & \multicolumn{3}{|c|}{ Factor } & \multirow{2}{*}{ Communalities } \\
\hline & 1 & 2 & 3 & \\
\hline Bank $\boldsymbol{X}$ service is ethical (Ethic1) & .761 & & & .741 \\
\hline Bank $\mathcal{X}$ transactions are transparent (Ethic2) & .705 & & & .755 \\
\hline Bank $\chi$ shows high integrity (Ethic5) & .609 & & & .713 \\
\hline $\begin{array}{l}\text { Bank } \chi \text { operation does not involve haram/ } \\
\text { immoral activities/investment (Ethic7) }\end{array}$ & .791 & & & .771 \\
\hline $\begin{array}{l}\text { Bank } X \text { contract started with promise/aqad } \\
\text { (Ethic8) }\end{array}$ & 686 & & & .649 \\
\hline $\begin{array}{l}\text { Bank } \mathcal{X} \text { service helps in fighting for the future of } \\
\text { Muslim economy (CSR3) }\end{array}$ & & .525 & & .610 \\
\hline $\begin{array}{l}\text { Bank } X \text { contributes back to the society through } \\
\text { social welfare service (CSR } 4 \text { ) }\end{array}$ & & .770 & & .736 \\
\hline $\begin{array}{l}\text { Bank } \mathcal{X} \text { contributes some portions of its profits } \\
\text { towards charity (sadaqah) (CSR5) }\end{array}$ & & .783 & & .773 \\
\hline $\begin{array}{l}\text { Bank } X \text { contributes to the alleviation of poverty } \\
\text { (CSR6) }\end{array}$ & & .646 & & .632 \\
\hline $\begin{array}{l}\text { Bank } \chi \text { helps to protect customers' belief on their } \\
\text { religion (Belief1) }\end{array}$ & & & .682 & .674 \\
\hline $\begin{array}{l}\text { Bank } \mathcal{X} \text { helps customers to conduct religiously } \\
\text { safe financial transactions (Belief3) }\end{array}$ & & & 656 & .737 \\
\hline $\begin{array}{l}\text { Bank } \mathcal{X} \text { provides assurance on the religious } \\
\text { acceptance of its financial service (Belief4) }\end{array}$ & & & .733 & .769 \\
\hline $\begin{array}{l}\text { Using bank } \chi \text { services may avoid customers from } \\
\text { punishment in the life after death on matters } \\
\text { related to interest ( riba) (Belief5) }\end{array}$ & & & .820 & .822 \\
\hline $\begin{array}{l}\text { Using bank } \chi \text { services helps customers to be } \\
\text { nearer to God (taqwa) (Belief10) }\end{array}$ & & & .708 & .680 \\
\hline
\end{tabular}


Finally, a reliability analysis was conducted which showed that each factor had a reliability coefficient above 0.8 as recommended by Hair et al. (2010), with 0.899 for ethics, 0.891 for CSR, and 0.923 for beliefs.

\subsection{Confirmatory Factor Analysis}

Upon completion of EFA, confirmatory factor analysis (CFA) was conducted on the remaining 244 responses. Confirmatory Factor Analysis (CFA) was conducted as a confirmatory test on the earlier measurement (Hair et al., 2010). The CFA results executed on the model shows a satisfactory result: $c^{2}{ }_{(74)}=158.376, c^{2} / \mathrm{df}=2.140$, $\mathrm{GFI}=.916$, CFI=.968, RMSEA $=.068$, and AGFI=.880. Inspection of the model shows that the factor loadings are all above .70. Although the value of AGFI is a bit low, the overall result shows a good fit of the measurement model. Figure 2 shows the measurement model for the spiritual brand attribute construct.

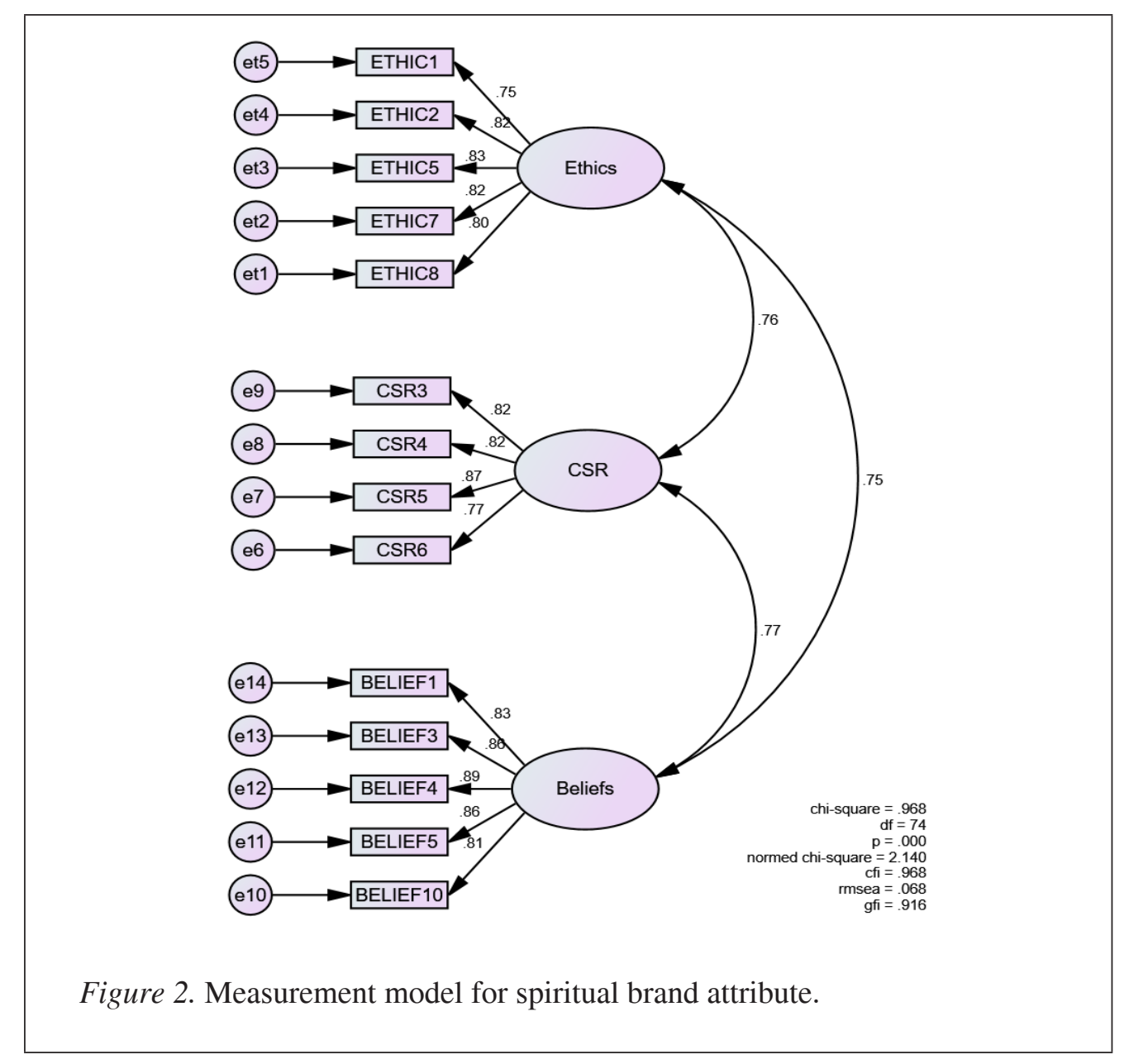




\subsection{Convergent Validity and Discriminant Validity}

After assessing the model fit, the convergent and discriminant validity of the model were examined. Table 2 displays the results of convergent and discriminant validity. The construct reliabilities are above 0.70 indicating adequate reliability (Hair et al., 2010). On the other hand, the AVE estimates for ethics, CSR and beliefs are 0.646, 0.676 and 0.723 respectively, which are above the $50 \%$ rule of thumb (Hair et al., 2010). The square root of the AVE estimates are higher than the correlations between dimensions (Fornell \& Larcker, 1981), and the correlation estimates of each dimension are below the cut-off value of 0.85 (Kline 2005) indicating the absence of discriminant validity.

Table 2

Reliability, Convergent and Discriminant Validity of the Spiritual Brand Attribute

\begin{tabular}{ccccccc}
\hline Dimensions & $\begin{array}{c}\text { Cronbach } \\
\alpha\end{array}$ & CR & AVE & Ethics & CSR & Beliefs \\
\hline Ethics & 0.899 & 0.901 & 0.646 & 0.804 & & \\
CSR & 0.891 & 0.893 & 0.676 & 0.759 & 0.822 & \\
Beliefs & 0.923 & 0.929 & 0.723 & 0.747 & 0.769 & 0.850 \\
\hline
\end{tabular}

\subsection{Nomological Validity}

Besides convergent and discriminant validity, nomological validity was also conducted. Based on previous studies, there is evidence to conclude that a relationship exists between brand attributes and brand image (Syed Alwi \& Kitchen, 2014). As such, the nomological validity between spiritual brand attribute and overall corporate brand image construct was tested. In doing so, the spiritual brand attribute was treated as a second-order construct.

The goodness-of-fit statistics shows that the model $c_{(131)}^{2}=270.954, c^{2} / \mathrm{df}=2.068$, $\mathrm{GFI}=.890, \mathrm{CFI}=.959$, RMSEA=.066, and AGFI=.856 fit the data well. Although GFI and AGFI are below .90, it is still considered a good fit (Etezadi-Amoli \& Farhoomand, 1996). As indicated in Table 3, all of the first-order constructs - ethics, CSR and beliefs have significant loadings $(\mathrm{p}<0.001)$ towards the overall brand image. The standardised regression coefficient between spiritual and image $(\square=.725)$ is also significant, indicating that the nomological validity of the model is established. Hence, based on these, there is evidence to support the construct validity of the model. 
Table 3

Nomological Validity of the Spiritual Brand Attribute

\begin{tabular}{lcccc}
\hline & $\begin{array}{c}\text { Std. } \\
\text { Estimate }\end{array}$ & S.E. & C.R. & P \\
\hline Ethics $\leftarrow$ Spiritual Brand Attribute & .877 & & Reference Point & \\
Beliefs $\leftarrow$ Spiritual Brand Attribute & .865 & .109 & 10.146 & $* * *$ \\
CSR $\leftarrow$ Spiritual Brand Attribute & .872 & .149 & 10.519 & $* * *$ \\
Image $\leftarrow$ Spiritual Brand Attribute & .725 & .119 & 9.245 & $* * *$ \\
\hline
\end{tabular}

\subsection{Discussion and Conclusions}

This study explores the spiritual aspect of the brand in the context of Islamic banks. First, the study provides assurance on the three dimensions of the spiritual brand attributes which are beliefs, ethics and CSR. Among the three, the study proposed a new dimension which is beliefs. Although ethics and CSR have been discussed by Maulan et al. (2016) and Osman (2011), both of them looked into the other aspect of branding such as brand association and image and do not consider functional and emotional brand attributes.

Second, the study provides evidence on the presence of the spiritual brand attribute, which is not similar to the concept of emotional or functional brand attributes. The study also supports Aoun and Turnois (2015) model of holistic branding which consists of the three dimensions of functional, emotional and spiritual dimensions. In addition, in line with the Gad (2003) 'brand mind space', the study also indicates that spiritual dimension is among the dimensions of brand.

Finally, the development of the spiritual brand attribute scale also illustrates the significance of religious influence on customers' evaluation of the attribute of the brand. This supported various early propositions on the importance of spiritual aspect in marketing halal products and services (Alserhan, 2010; Temporal, 2011; Wilson, 2012). The inclusion of the beliefs dimension also shows that the religious aspect is not only important in the 'form' of the Islamic bank but is also essential to be incorporated in its 'substance'.

Managerially, there are several contributions that could be suggested to the bank management. First, although the aspect of beliefs has been less emphasized by Islamic banks in their recent marketing effort, it is still an important feature to Muslim consumers. Thus, in order to maintain its appeal towards the banks' main target market, which are the Muslims, it is recommended for the bank to not dissociate themselves 
from the importance of beliefs. The main reasons to use Islamic bank as compared to the conventional banks could be promoted through various ways including publicity and viral messages to gain wider attention (Berry, 2000).

In addition, as the study shows that CSR is also important in the evaluation of spiritual brand attribute, the bank is also recommended to publicise its CSR activities through various mediums including mass media and social media. Not only that, it should also be a policy at the higher level to ensure that all Islamic banks contribute zakat and perform community services so that a clear association between the banks and their spiritual attributes could be apparent.

Finally, it is also significant for the Islamic banks to always ensure that the banks have an ethical image. This is important as the banks are not only business entities, but one that carries an Islamic brand name. As such, any unethical conduct by the bank would not only affect the business organization, but also shake the image of the religion. In order to portray an ethical identity, it is important for the banks to follow the Islamic teaching in total, and to ensure the achievement of the maqasid al-shari'ah as it would become a basis for the society to evaluate the bank compliance with religious teachings.

In short, the study has presented the spiritual brand attribute dimensions of Islamic bank. Findings of the study are in line with Maulan et al. (2016) and Osman (2011) also Aoun and Tournois (2015). However, there are several limitations that need to be kept in mind in generalising the study. First, data was collected using non-random sampling technique which limits its generalizability to a wider audience. As such, findings of this study could only represent the sample and additional studies need to be conducted to ensure it is applicable to the other customer groups. Second, despite the consideration of functional and emotional aspects in developing the spiritual brand attribute scale, the quantitative part of the study focused on the spiritual aspect only. As such, future studies are needed to test all the three attributes together so that a better understanding of the simultaneous impact of these dimensions could be achieved.

\section{Acknowledgement}

An earlier version of this paper was presented at the IIUM International Conference on Business Management in Kuala Lumpur, Malaysia. The authors thank the reviewers and participants at this conference for their valuable insights.

\section{References}

Abduh, M. (2011). Islamic banking service quality and withdrawal risk: The Indonesian experience. International Journal of Excellence in Islamic Banking and Finance, 1(2), 1-15. 
Ahmad, A., Kashif-ur-Rehman, \& Humayoun, A. A. (2011). Islamic banking and prohibition of riba/interest. African Journal of Business Management, 5(5), 1763-1767. Retrieved from http://www.academicjournals.org/AJBm/ fulltext/2011/4Mar/Ahmad et al 2.htm

Ahmad, K. (2000). Islamic finance and banking: the challenge and Prospects. Review of Islamic Economics, 9, 57-82.

Ahmad, M., \& Khan, S. (2016). A model of spirituality for ageing Muslims. Journal of Religion and Health, 55(3), 830-843.

Ali, A. H. (1995). The nature of human disposition: Al-Ghazali's contribution to an islamic concept of personality. Intellectual Discourse, 3(1), 51-64.

Alserhan, B. A. (2010). On Islamic branding: Brands as good deeds. Journal of Islamic Marketing, 1(2), 101-106.

Aoun, I., \& Tournois, L. (2015). Building holistic brands: An exploratory study of halal cosmetics. Journal of Islamic Marketing, 6(1), 109-132.

Beekun, R. I., \& Badawi, J. A. (2005). Balancing ethical responsibility among multiple organizational stakeholders: The Islamic perspective. Journal of Business Ethics, 60(2), 131-145.

Berry, L. L. (2000). Cultivating service brand equity. Journal of the Academy of Marketing Science, 28(1), 128-137. https://doi.org/10.1177/0092070300281012

Bonab, B. G., Miner, M., \& Proctor, M.-T. (2013). Attachment to God in Islamic Spirituality. Journal of Muslim Mental Health, 7(2), 77-104. https://doi. org/10.3998/jmmh.10381607.0007.205

Dasti, M. R., \& Sitwat, A. (2014). Development of a multidimensional measure of Islamic spirituality (MMS). Journal of Muslim Mental Health, 8(2), 1556-4908. https://doi.org/10.3998/jmmh.10381607.0008.204

de Chernatony, L. (2002). Would a Brand Smell any Sweeter by a Corporate Name? Corporate Reputation Review, 5(2/3), 114-132. https://doi.org/10.1057/ palgrave.crr.1540169

de Chernatony, L., \& Christodoulides, G. (2004). Taking the brand promise online: Challenges and opportunities. Interactive Marketing, 5(3), 238-251.

de Chernatony, L., \& Dall'Olmo Riley, F. (1999). Experts' views about defining services brands and the principles of services branding. Journal of Business Research, 46(2), 181-192. https://doi.org/10.1016/S0148-2963(98)00021-6

Dusuki, A. W. (2008a). Understanding the objectives of Islamic banking: A survey of stakeholders' perspectives. International Journal of Islamic and Middle Eastern Finance and Management, 1(2), 132-148. https://doi. org/10.1108/17538390810880982

Dusuki, A. W. (2008b). What does Islam say about corporate social responsibility? Review of Islamic Economics, 12(1), 5-28. https://doi.org/10.2190/86QBKKY1-F27L-3KHK

El-Amir, A., \& Burt, S. (2010). A critical account of the process of branding: Towards a synthesis. The Marketing Review, 10(1), 69-86. 
Emmons, R. A. (2006). Spirituality. In a life worth living: Contributions to positive psychology (pp. 62-81). New York: Oxford University Press.

Etezadi-Amoli, J., \& Farhoomand, A. F. (1996). A Structural Model of End Eser Computing Satisfaction and User Performance. Information and Management, 30(2), 65-73. https://doi.org/10.1016/0378-7206(95)00052-6

Fornell, C., \& Larcker, D. F. (1981). Evaluating structural equation models with unobservable variables and measurement error. Journal of Marketing Research, 18(1), 39-50. https://doi.org/Article

Gad, T. (2003). Leadership Branding. In N. Ind (Ed.), Beyond branding : How the new values of transparency and integrity are changing the world of brands (pp. 183-198). London: Kogan Page Limited.

Gray, D. E. (2004). Doing research in the real world. London: Sage Publications.

Hair, J. F., Black, W. C., Babin, B., Anderson, R. E., \& Tatham, R. L. (2006). Multivariate Data Analysis. New Jersey: Pearson International Edition.

Hair, J. F., Black, W. C., Babin, B. J., \& Anderson, R. E. (2010). Multivariate data analysis (7th edn.). Upper Saddle River, New Jersey: Pearson Prentice Hall.

Ismail, N., \& Muqorobin, A. (2017). Implementation of Corporate Social Responsibility (CSR) on Islamic Banking: Maqasid Sy ariah's Approach. Islamic Economics Journal, 3(1), 75-91. Retrieved from https://www.ejournal.unida.gontor.ac.id/ index.php/JEI/article/view/1384

Mansour, W., Ben Jedidia, K., \& Majdoub, J. (2015). How ethical is islamic banking in the light of the objectives of Islamic law? Journal of Religious Ethics, 43(1), 51-77. https://doi.org/10.1111/jore.12086

Marmor-Lavie, G., Stout, P. A., \& Lee, W.-N. (2009). Spirituality in advertising: A new theoretical approach. Journal of Media and Religion, 8(1), 1-23. https://doi. org/10.1080/15348420802670868

Maulan, S., Omar, N. A., \& Ahmad, M. (2016). Measuring halal brand association (HalBA) for Islamic banks. Journal of Islamic Marketing, 7(3), 331-354. https:// doi.org/10.1108/JIMA-09-2014-0058

Md Husin, M., \& Ab Rahman, A. (2013). The role of brand in the Malaysian takaful industry. Jurnal Teknologi (Social Sciences), 63(1), 1-6. https://doi. org/10.11113/jt.v63.1358

Mohammad, M. O., \& Shahwan, S. (2013). The objective of Islamic economic and Islamic banking in light of maqasid al-shariah : A critical review. MiddleEast Journal of Scientific Research, 13, 75-84. https://doi.org/10.5829/idosi. mejsr.2013.13.1885

Mourad, M., \& Karanshawy, H. El. (2013). Branding Islamic studies: exploratory study in the Middle East. Journal of Islamic Marketing, 4(2), 150-162. https:// doi.org/10.1108/17590831311329287

Osman, 'Ismah. (2011). The impact of corporate image on customer loyalty of Islamic Banks in Malaysia: Integrating resource-based and institutional theory. International Islamic University Malaysia. 
Othman, A., \& Owen, L. (2001). Adopting and measuring customer service quality (SQ) in Islamic Banks: A case study in Kuwait Finance House. International Journal of Islamic Financial Services, 3(1), 1-26.

Pallant, J. (2005). SPSS survival manual (2nd edn.). New South Wales: Allen \& Unwin.

Parasuraman, A., Zeithaml, V. A., \& Malhotra, A. (2005). E-S-QUAL: A multiple-item scale for assessing electronic service quality. Journal of Service Research, 7(3), 213-233. https://doi.org/10.1177/1094670504271156

Park, W., Jaworski, B. J., \& Maclnnis, D. J. (1986). Strategic brand concept-image management. Journal of Marketing. https://doi.org/10.2307/1251291

Ramayah, T., Cheah, J., Chuah, F., Ting, H., \& Memon, M. A. (2018). Partial Least Squares Structural Equation Modeling (PLS-SEM) using SmartPLS 3.0. Kuala Lumpur: Pearson Malaysia Sdn Bhd.

Sekaran, U. (2000). Research methods for business: A skill building approach (3rd edn.). New York: John Wiley \& Sons.

Sekaran, U. (2003). Research method for business: A skill building approach (Fourth Edi). New York: John Wiley \& Sons, Inc.

Syed Alwi, S. F., \& Kitchen, P. J. (2014). Projecting corporate brand image and behavioral response in business schools: Cognitive or affective brand attributes? Journal of Business Research, 67(11), 2324-2336. https://doi.org/10.1016/j. jbusres.2014.06.020

Temporal, P. (2011). Islamic Branding and Marketing. Singapore: John Wiley \& Sons. Warde, I. (2000). Islamic Finance in the Global Economy. Edinburgh: Edinburgh University Press.

Wilson, J. (2012). Looking at Islamic marketing, branding and Muslim consumer behaviour beyond the 7P's: The call for supportive course content and more P's please. Journal of Islamic Marketing, 3(3), 212-216. https://doi. org/10.1108/17590831211259718 


\section{Appendix A. Selected interviews excerpts}

"go for Islamic bank is actually align with our beliefs"

"we use Islamic bank because we want to protect our beliefs"

"it's like taqwa. We try to find what Allah likes. Since Allah says don't take riba."

"I agree that Islamic bank exist on the basis of tauhid. Its just we are not emphasizing it in our marketing. Non-Muslims may see Islamic bank as a business entity. Muslims see Islamic bank as a necessity to be in accordance with their belief"

"Islamic bank is related with the hereafter. It's for the world and the hereafter"

"we use Islamic bank as we try to avoid the punishment in the hereafter"

"Islamic bank is providing choice for a safer route. It's not easy to answer in the hereafter. At least in the hereafter I could answer with peace-of-mind, I have choose something Islamic"

"The most important thing, Islamic bank will help you to avoid riba and avoid sin..."

"For Islamic bank we always have this thing call CSR. CSR by the way is the bank DNA. Because all our revenues are contributed back in terms of zakat. So our zakat is our DNA. So in our bank you can see all the activities we have done for the community in the website... so our bank is famous with doing charity..."

"so we must always tell people about our concerns to the profit, to the community, to the planet..."

"...so actually Islamic bank is helping to protect the Muslims economy. Because we provide the avenue... so Islam bank is fighting for the economy and future of the Muslims"

"but now Islamic bank is doing a lot.. develop economy, give works to people, help people in need, education financing, if you don't have money to further study, you can go to the bank. Want to buy a house, that is actually daruriyyah, necessity... so that's mean we are helping towards maqasid shari'ah as well"

"... following the halal and haram guideline. There is no gambling, no activities like... thing that not (allowed) to do"

"...so if you have integrity, you have integrity, if you are being trusted, you need to be trustworthy. So actually if we all follow $100 \%$ the bank will be very successful" 
“...because we (Islamic bank) have high components of ethics and morality"

"...to be ethical you must go in depth to the principle, to the aqad, things that makes it comply to the shari'ah" 


\section{Appendix B. Items remain after content validity}

\begin{tabular}{ll}
\hline Categories & Items \\
\hline Beliefs & Bank $\mathcal{X}$ helps to protect customers' belief on their religion. \\
Bank $\mathcal{X}$ helps to fulfil customers' religious obligations. \\
Bank $\mathcal{X}$ helps customers to conduct religiously safe financial \\
transactions. \\
Bank $\mathcal{X}$ provides assurance on the religious acceptance of its financial \\
service. \\
Using bank $\mathcal{X}$ services may avoid customers from punishment in the life \\
after death on matters related to financing. \\
Using bank $\mathcal{X}$ services provide peace-of-mind on matters related to life \\
after death. \\
Bank $\mathcal{X}$ business concept covers the world and the life after death. \\
Bank $\mathcal{X}$ business concept provides security in the life after death. \\
Bank $\mathcal{X}$ services help customers to avoid sin on financial related matters. \\
Using bank $\mathcal{X}$ services helps customers to be nearer to God (taqwa). \\
Bank $\mathcal{X}$ service helps customers to follow their belief towards God's \\
command on financial related matters.
\end{tabular}

Ethics

Bank $\mathcal{X}$ service is ethical.

Bank $\mathcal{X}$ transactions are transparent.

Bank $\mathcal{X}$ operation is shariah compliance.

Bank $\mathcal{X}$ approach seems humble (tawadhu).

Bank $x$ shows high integrity.

Bank $\boldsymbol{x}$ operation follows Islamic teaching.

Bank $\mathcal{X}$ operation does not involve haram/immoral activities/ investments.

Bank $\mathcal{X}$ contract started with promise/aqad.

CSR Bank $\chi$ service helps to improve Muslim economy.

Bank $\mathcal{X}$ service is important in protecting the interest (maslahah) of the Muslim community.

Bank $\mathcal{X}$ service helps in fighting for the future of Muslim economy.

Bank $x$ contributes back to the society through social welfare service.

Bank $\chi$ contributes some portions of its profits towards charity (sadaqah). 


\section{Categories Items}

Bank $\chi$ contributes to the alleviation of poverty.

Bank $x$ contributes some portions of its profits towards the payment of zakat (almsgiving).

Bank $x$ provides services for people in need.

Bank $\chi$ service helps people to fulfil their necessities. 